\title{
HOW TO BECOME A SUCCESFUL LANGUAGE LEARNER LEARNER AUTONOMY, STYLES AND STRATEGIES REVISITED
}

\author{
Inez De Florio-Hansen
}

\begin{abstract}
The aim of the present paper is to revisit the construct of learner autonomy and its interrelatedness with learning styles and learner strategies in the context of foreign language learning. In a brief overview the role of learning and teaching languages, especially English, is considered in the context of globalization. In the following, autonomy is defined and described drawing on examples of my own learning of Turkish. The presentation of several approaches to learner autonomy leads to an integrated model of self-directed learning. Then, I deal with styles and strategies in a task-based approach. Furthermore, a taxonomy of learner strategies for acquiring speech acts is provided.
\end{abstract}

Key words: learner autonomy, learning styles, learner strategies, self-directed learning, task-based learning, EFL, intercultural pragmatics, speech acts.

\section{BİR YABANCI DİL EN ETKİLİ BICÇIMDE NASIL ÖĞRENILİR? ÖĞRENCI OTONOMISİ, ÖĞRENME STILLERİ VE ÖĞRENME STRATEJILERINE YENİ BİR BAKIŞ AÇISI}

\footnotetext{
$\ddot{O} z e t$

Çalışmanın amacı yabancı dil öğreniminde öğrenci otonomisini sağlama ve bunun öğrenme stilleri ve ögrenme stratejileri ile olan ilişkilerini değişik bir baklş açısıla incelemektir. Yazımın başlangıcında genel bakış itibariyle, yabancı dil ögrenmenin ve öğretmenin globalleşme süreci içerisindeki rolü (özellikle İngilizce) ele alınmıştır. Bunlara ilaveten, yabancı dil öğrenimi açısından otonominin tanımı yapılmakta ve içeriği açıklanmaktadır. Bu açıklamalarda, öğrenme sürecini yönlendiren bir ögretmen olmadan, kendi kendini yönlendirme yoluyla Türkçe ögrendiğim süreç içerisinde edindiğim tecrübeler hakkındaki örneklere yer ayrılmıştır. Sonuç olarak öğrenci otonomisi konusunda meydana getirilmiş çeşitli teoriler, bizi birey tarafindan belirlenen entegre bir ögrenme modeline götürmektedir. Bunların yanında göreve dayalı yabancı dil öğrenimi açısından ögrenme stilleri ve ögrenci stratejilerine yer verdim. Çalışmamım sonunda konuşma davranışlarını (speech acts) ve ögrenme stratejilerinin bir taksonomisini sunmaktayım.

Anahtar sözcükler: Öğrenci Otonomisi, Öğrenme Stilleri, Öğrenci Stratejileri, Kendi Kendine Ögrenme, Göreve Dayalı Ögrenme, Yabancı Dil Olarak Ingilizce, Kültürlerarası Pragmatik, Konuşma Davranışları
} 


\section{Globalization and language learning}

It is a truism to state that we are living in an increasingly globalized world. Globalization has been defined by Giddens (1990: 64) as "the intensification of worldwide social relations which link distant localities in such a way that local happenings are shaped by events occurring many miles away and vice versa". Whereas this definition is generally accepted, there is much disagreement about related issues. Some consider globalization as an expression of Western hegemony, and above all as an extension of American imperialism. Others see the process as more egalitarian and reject discussions in terms of Western dominance over "the rest" (Block 2004: 75). In the context of Applied Linguistics and Foreign Language Pedagogy we opt for a transformationalist view which Block (2004: 76) puts as follows: "... we are living in an age of greater upheaval and change, with unprecedented levels of interconnectedness among nation states and local economies and cultures, which are thanks in part - though not exclusively - to technological developments".

The intensification of worldwide social relations and the interconnectedness of nation states, their economies and cultures has brought about an increase in the learning of second and foreign languages all over the world. In the past few decades English has become the world's global language. "Around one in five of the world's population speaks English, and English has become the language of international commerce, popular culture and the Internet" (foreword by HRH The Prince of Wales, Graddol 1997). As global communication is dominated by the English language, a good command of English is considered a key qualification in most parts of the world. When we deplore the continued global dominance of English, we should take into account that linguistic imposition or "linguistic imperialism" (Phillipson 1992; Cherrington 2000) is costing us a heavy price. The fact that so many people use English as a second or a foreign language for their own purposes has led to a decline of the English language, especially of British English (for an overview see Graddol 1997 and Widdowson 2000). However, it is equally true to say that the status of English as a world language offers exciting possibilities to all people willing to share their experiences. A good knowledge of English enables us not only to communicate in professional and private contexts but also to take an active part in ongoing processes of upheaval and change. The spread of English is "altogether too complicated to be considered benign or evil" (Block 2004: 76). 


\section{Globalization and language teaching}

The rise of the popularity of English has been linked to the former colonial strength of Britain and in more recent decades to the power of the USA. However, there is another important issue to be taken into account. Any other colonial language, such as French or Spanish, might have attained a predominant position if the spread of English had been left to chance. In the immediate post-war period there was active promotion through political and economic factors. "...ELT [English Language Teaching] became a large and expanding business, supported by academic and linguistic developments and also by governments and their agencies" (Cherrington 2000: 361). Whereas there was a sort of "implicit hyperglobalism' which envisaged the entire world learning English via one dominant methodology and one particular type of pedagogical material, recently there has been a more reflective approach to language teaching methods and their transferability (Block 2004: 76; see also Kramsch and Sullivan 1996).

That it is no longer possible to disseminate one particular approach to language teaching around the world is partly due to the efforts of ELT professionals. In the past few decades they have begun to consider the social, political and economic factors which come into play when methods and materials cross borders. Furthermore, developments in Applied Linguistics and Foreign Language Pedagogy, which were influenced by research into second language acquisition and foreign language learning, have put an increasing emphasis on the individual language learner. The concept became widespread as 'learner-centredness'. Besides motivation, learning styles and learner strategies are considered as crucial to success in language learning. An important concept entwined in various ways with styles and strategies is that of learner autonomy, i.e., the capacity to take control over one's own learning. Prominent researchers (e.g., Dam 1995; Dickinson and Wenden 1995; Benson and Voller 1997; Legenhausen 1999; Vieira 1999) and practitioners regard learner autonomy as a precondition for effective learning. Furthermore, the current processes of upheaval and change constrain most of us to lifelong learning, which is at least partly synonymous with autonomous learning.

As there is much terminological and conceptual confusion and little empirical evidence, many teachers may feel hindered from helping students to become more autonomous language learners. In the following sections I will shed some light on the aforementioned concepts with reference to practice, particularly with reference to teaching and learning English as a foreign language. Following Benson (2001: 2), I take the position "that autonomy is a legitimate and desirable goal of language education". "Yet we should also recognize that pedagogical decisions in respect to autonomy are often based upon underlying philosophical and political 
assumptions" (Benson 2001: 46). Thus, concerns about the cultural appropriateness of the idea of autonomy in language learning will be discussed. On the other hand, autonomy takes different forms for different learners and its manifestations vary according to cultural contexts. It is up to every teacher and the learners of whom he or she is in charge, to try out what makes sense in the specific conditions of teaching and learning within which they work.

\section{Autonomy in language learning}

\subsection{Definitions of learner autonomy}

To its advocates the development of autonomy implies better language learning. But what does autonomy really mean? The construct refers to the learner's broad approach to the learning process. We all know the frequently cited definition by Holec (1981: 3):

To take charge of one's own learning is to have, and to hold, the responsibility for all decisions concerning all aspects of this learning, i.e.:

- determining the objectives;

- defining the contents and progressions;

- selecting methods and techniques to be used;

- monitoring the procedure of acquisition properly speaking (rhythm, time, place, etc.)

- evaluating what has been acquired.

It is not Holec's fault that his definition has led to misconceptions. Little (1990: 7) makes a useful statement on what autonomy is not:

- Autonomy is not a synonym for self-instruction; in other words, autonomy is not limited to learning without a teacher.

- In the classroom context, autonomy does not entail an abdication of responsibility on the part of the teacher; it is not a matter of letting the learners get on with things as best they can.

- On the other hand, autonomy is not something that teachers do to learners; that is, it is not another teaching method.

- Autonomy is not a single, easily described behaviour.

- Autonomy is not a steady state achieved by learners. 
Despite such explanations as Little's many practitioners view the construct of learner autonomy as being synonymous with self-access and especially with technology-based learning. Even nowadays autonomy is often associated with learning in isolation, outside the classroom and without a teacher. This is a very partial view. Since the capacity of taking charge of one's own learning is not innate but must be learned and developed, there is much need for guidance. It is the complex task of teachers to help their students to become more autonomous in their language learning.

Furthermore, misguided conceptions of autonomy in language learning may also be used for politically ambiguous ends. The world wide expansion of language learning and the fact that language skills represent a form of economic capital have brought about consumerist approaches, with a shift in focus from the goals and purposes of language learning to the skills and strategies employed by the autonomous learner. In higher education in particular there is a trend to reduce teacher contact time and thus achieve reductions in unit costs. Benson (2001:21) concludes:

Although the idea of autonomy currently appears to be in harmony with the need for skilled language learners within a global economy, it does not arise from these needs, nor is it dependent upon them. Autonomy is fundamentally concerned with the interests of learners, rather than the interests of those who require their skills.

Based on constructivist and social theories within the psychology of learning and other important concepts beyond the field of language education (see figure 1), researchers such as Dam (1995) and Little (1996) underscore the social character of all learning, even of learning to take control over the cognitive processes involved in effective self-management.

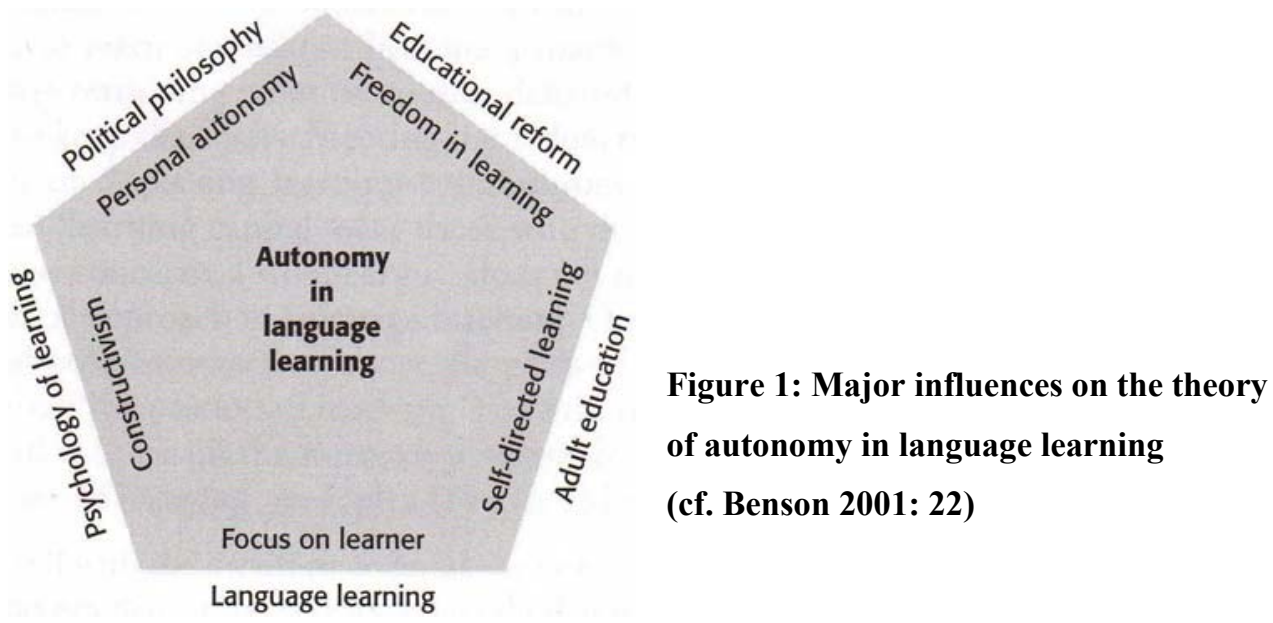


Autonomy thus implies interdependence, i.e., the ability to cooperate with others and solve conflicts about learning (and beyond) in constructive ways. In order to help teachers to promote self-organized, self-regulated learning in the language classroom, autonomy has to be described in terms of observable (and researchable) behaviors. This leads us to a slight modification of Holec's definition. Benson (2001: 47) prefers "to define autonomy as the capacity to take control of one's own learning, largely because the construct of 'control' appears to be more open to investigation than the construct of 'charge' or 'responsibility".

\subsection{Describing autonomy in language learning}

Despite cultural differences language learning includes phases of selfinstruction. ${ }^{0}$ From learner diaries and oral statements, we know that these phases often take place in the language classroom. Learners normally follow their own agendas. As all learning is highly individual, there is a natural tendency for the learner to take control over his or her own learning. From research into individual learner differences we can conclude that effective learning occurs when learners are free to learn in the ways that suit them best.

Teachers can help their students to find out what works best for them. Many individual learner variables are mutable - Ellis (1994: $472 \mathrm{f}$.) presents a continuum based on mutability - , and changes may occur through reflection and training.

But at what levels can language learners exercise control over their learning? Returning to Holec's definition, we can summarize his considerations in terms of three interdependent levels of control. Autonomous learners are able to manage

1. the planning of their learning,

2. its organization and

3. its evaluation.

\section{An example of self-directed learning of Turkish as a foreign language}

About two years ago I decided to learn another foreign language. Since I had a good command of German, English, Italian and French and a passive knowledge of Spanish, I was in search of a language not too close to the languages I had already learned. I wanted to explore something new regarding vocabulary, grammar and pragmatic conventions. My overall aim, however, is to state the results of my own autonomous language learning in terms of proficiency.

\footnotetext{
${ }^{0}$ Self-instruction can be defined as any deliberate effort by the learner to acquire or master language content or skills. It is episodic, and may take place inside or outside the classroom (Dickinson 1987: 5).
} 
As studying a foreign language is closely linked to intercultural learning, I have decided to learn Turkish, the mother tongue of more than two million people living in the Federal Republic of Germany. I think that my approach to Turkish will, among other things, help me gain a better understanding of the needs and interests of children and adolescents of Turkish origin. My studies of Turkish might enable me to contribute more effectively to the development of bi- and multilingualism of Turkish migrants and their children. ${ }^{0}$

Before I started with the actual language learning, I read several books about Turkey, especially about the origins and recent developments of the Turkish language. To become acquainted to the sounds of Turkish I watched Turkish TV programmes as well as some documentaries and movies available on DVD subtitled in English or German.

The choice of a textbook was a great challenge. I decided against a software or online course because I wanted to be able to carry the learning materials around with me all the time. I consulted several course books without finding something really interesting except for "Türkisch mit Gedichten" (Şiirle Türkçe Öğrenmek; Hepsöyler and Liebe-Harkort 1995). This book presents contemporary Turkish poems with annotations and exercices for advanced German-speaking learners of Turkish. Print courses for beginners available in Germany, however, do take account of recent developments in Applied Linguistics and Foreign Language Pedagogy. In general, they follow a traditionalist approach whose main focus is on grammar. Far from being authentic, the texts, which consist mainly of dialogs, are centred around new grammatical forms. Having nothing better at hand, I opted for a 24-unit self-learning course (Langenscheidts Praktisches Lehrbuch Türkisch 1997) which introduces beginners to the most important structures of Turkish.

In the beginning my (self-directed) learning followed the procedures that characterize many foreign language classrooms: reading the dialogs, listening to the recordings on $\mathrm{CD}$, learning vocabulary and studying grammar. Then, I did the exercises in the course book, manipulating pieces of language without any clear communicative aim.

After some weeks I began to look for help, from a consultant rather than a teacher. The explanations of grammatical features were quite clear, but the examples in the course book and in other (systematic) grammar books of Turkish available to me did not explain pragmatic conventions. Why iyi akşamlar (Have a

\footnotetext{
${ }^{0}$ Current research into the linguistic development of Turkish children and adolescents focuses mostly on (preschool) diagnostic proficiency tests in German. The bulk of relevant research does not take account of the differences which can be found between Basic Interpersonal Communicative Skills (BICS) and Cognitive Academic Language Proficiency (CALP), the latter being necessary to follow subject matter courses in primary and secondary schools.
} 
nice evening!) in the plural? Why so many greeting forms? Why such an indirect way to express suggestions and requests? As most of my questions were linked to current Turkish culture, I was in search of a person socialized in Turkey who had recently come to Germany. I found that person in a student from Istanbul participating in a master program of German as a foreign language at our faculty where he is now a doctoral student. Since he had an excellent command of German and was acquainted to the problems of teaching and learning foreign languages, he was able to assist me in my learning process, which nevertheless remained selfdirected. (For more details about the organization of my learning process see below.)

\subsection{Some consequences for the development of learner autonomy}

What conclusions can we draw from this example? First of all, my experience proves once more that all learning of a foreign language with communicative aims - as autonomous it may be - is based on interaction. Furthermore, the example shows implicitly that successful learning - inside and outside the classroom depends on the answers to the following questions:

-What are we doing?

- Why are we doing it?

- How are we doing it?

- With what results? What can it be used for?

Before introducing her simplified model of a teaching/learning sequence, Dam (1999) points out that in a formal educational context such as in schools or university courses, total learner autonomy does not exist, but that a development towards greater control of the learners over their own learning can be initiated by classroom discussions about learning outcomes. How to move from a teacherdirected environment towards a possible learner-centered environment is illustrated by the following model (Dam 1999:116):

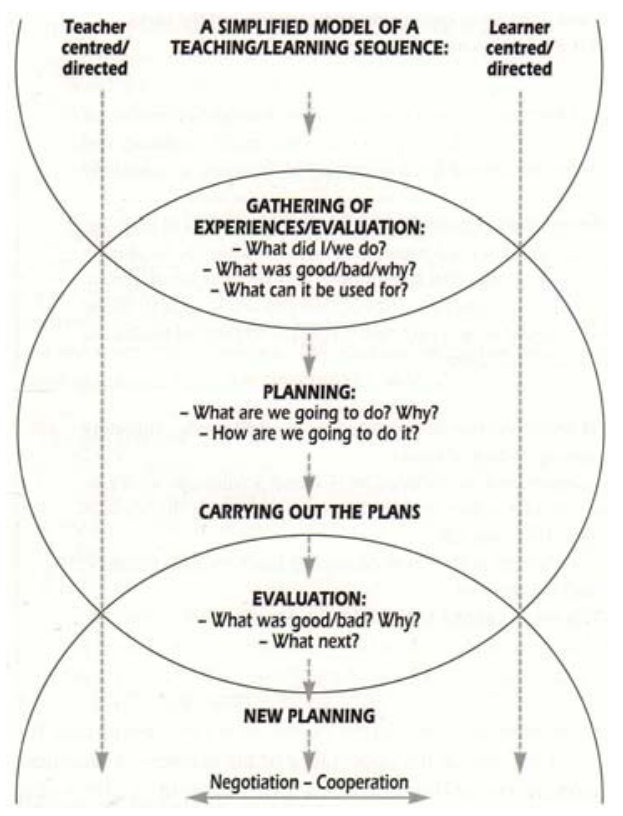

Figure 2: The three cycles 
When Dam underscores the impossibility of total autonomy in the foreign language classroom, she refers to control over content, i.e., the right of learners to determine and implement their own learning goals. In fact, the "ownership" of learners is limited by the curriculum and the derived syllabuses. Moreover, what is valid for content applies to evaluation, too. We can distinguish between an internal self-directed assessment and an external other-directed evaluation.

As the main goals of learning a second or foreign language, however, are shared all over the world, there is no reason to withdraw from learner development. Even though there may be local constraints due to external factors, all teachers can help their students to develop an active, independent attitude to language learning and language use. As autonomy can be fostered most effectively through a combination of approaches (Benson 2001: 177), I will show in the following subsections how important aspects of different approaches may be integrated in such a way as to help learners change their view of language learning.

\section{Approaches to learner autonomy}

Benson (2001: $107 \mathrm{ff}$.) distinguishes between six main approaches to learner autonomy:

(1) resource-based approaches,

(2) technology-based approaches,

(3) learner-based approaches,

(4) classroom-based approaches,

(5) curriculum-based approaches,

(6) teacher-based approaches.

The first two approaches are inextricably entwined: self-access centers, selfinstructional materials and distance learning often rely on CALL (Computer Assisted Language Learning) and CMC (Computer Mediated Communication) via the Internet. Although until now there is little empirical evidence of the potential of new technologies in regard to learner autonomy, it seems that both approaches provide the learners with opportunities to self-direct their own learning. In my opinion, the results - learning outcomes as well as an increased control over learning - depend primarily on the teacher's ability to guide his or her students towards a reflective use of all materials and media at their disposal.

Learner-based approaches place the main emphasis on behavioral and psychological changes that enable learners to take greater control of their learning and thus help them become better language learners. The above mentioned learning styles as well as strategies of language learning and language use are at the very 
heart of this approach. For many researchers and practitioners, explicit training of strategies leads directly to learner autonomy. However, it is important to distinguish strategies from other learning processes that are not strategic, but that can be raised to consciousness and that are mutable through reflection. This does not mean that styles and strategies are irrelevant, but they are only one possible approach to learner autonomy. Cohen (1998: $66 \mathrm{f}$.), thus, tries to avoid the pitfalls of an overemphasis on explicit strategic instruction in learner development (for an example of strategy training and use see section 5 below).

The overall aim of learner-based approaches is to change the learners' view of learning, i.e., guiding them from completing tasks set by others to constructing knowledge for themselves. This can be reached through reflection on learning materials and activities, e. g., consciousness-raising discussions of available resources, presenting and practicing techniques to exploit resources, introduction to the theoretical constructs of language acquisition underlying the selection of resources and techniques (Wenden 1991). In my opinion, integrated approaches (see Legutke and Thomas 1991) are more appropriate for language teachers who aim at enabling their students to become better learners and at preparing them for lifelong language learning.

For this reason, classroom-based approaches could not be separated from the other concepts mentioned above. With classroom-based approaches, Benson (2001: $151 \mathrm{ff}$.) puts the emphasis on changes in the relationships within conventional educational structures. Planning classroom learning together with the students means encouraging self-management in learning. Nevertheless, even in studentdirected classes learners have to be supported in their learning. They must have the feeling that they can call on the assistance of the teacher when necessary. What is true for learning in an educational setting is also valid outside the classroom. Even in self-directed learning, there is quite often a need for support in the form of a consultant or a coach. Besides the planning of learning activities, another main focus of classroom-based approaches is on evaluation of learning outcomes. There is empirical evidence that self-assessment improves reflection and motivation (see e.g. Oscarson 1997).

It is quite clear that day-to-day decisions and classroom roles are conditioned by broader institutional, social and discursive practices, e.g., external tests and curricular guidelines. Nevertheless, critical discussion of the purposes of existing procedures can give learners a feeling of ownership of their learning even if it is not possible to negotiate the goals and content of their learning. Curriculumbased approaches which focus on process syllabuses, i.e., a specification of aims and a selection and grading of content influenced mainly by the language learners themselves, are out of reach in most educational settings. As communicative 
intercultural competence is the worldwide accepted goal of second and foreign language learning, task-based learning (see Ellis 2003) and project work (examples for ELT see Legutke and Thomas 1991) already offer an abundance of opportunities for exerting an influence on content and procedures.

Furthermore, it is evident that without teacher autonomy (as claimed by those sustaining teacher-based approaches) learner autonomy can hardly ever be put into effect.

The idea of teacher autonomy arises in part from a shift in the field of teacher education from a focus on the teacher as a conduit for methods devised by experts to a focus on the teacher as a self-directed learner and practitioner [...]. It also arises from a growing awareness among teachers involved with learner autonomy of the importance of their own role in the process of helping learners take greater control over their learning (Benson 2001: 173).

\subsection{An integrated model of self-directed learning}

Although I take the position that learner "autonomy" is an important goal of language learning, and adopting the definition of Benson who lays emphasis on control rather than responsibility for all learning aspects (see 3.1 above), I prefer the term of self-directed (language) learning. In my opinion, autonomy is a wider concept linked to and even synonymous with personal authenticity, i.e., the quality of being genuine or true as an individual acting according to one's own beliefs. In this broader sense, autonomy is sometimes used as a pretext for letting learners insist on their own views or ways of learning, although the experienced teacher knows that his or her student's beliefs and behavior will not lead to successful language learning.

Looking at autonomy beyond the field of language education, Benson (2001: 34 ), in a discussion which takes adult education as its starting point, argues as follows:

Self-direction tends to refer to the learner's global capacity to carry out such learning effectively, while autonomy often refers to the particular personal or moral qualities associated with this capacity.

In the field of language learning, it is autonomy that defines both the broad field of inquiry and the global capacity to exercise control over one's learning. Self-directed learning tends to refer simply to learning that is carried out under the learner's own direction, rather than under the direction of others (emphases by the author). 
It is in fact the distinction between attributes of the learner (autonomy) and particular modes of learning (self-direction) which motivates my preference for the term of self-directed language learning. Autonomy being a process of lifelong learning and adaptation, the term of self-direction in language learning may lead us to set more realistic goals for our students.

At the very heart of the following model is self-directed language learning inside and outside the classroom. Self-direction is based, among other things, on the following intricately interrelated aspects:

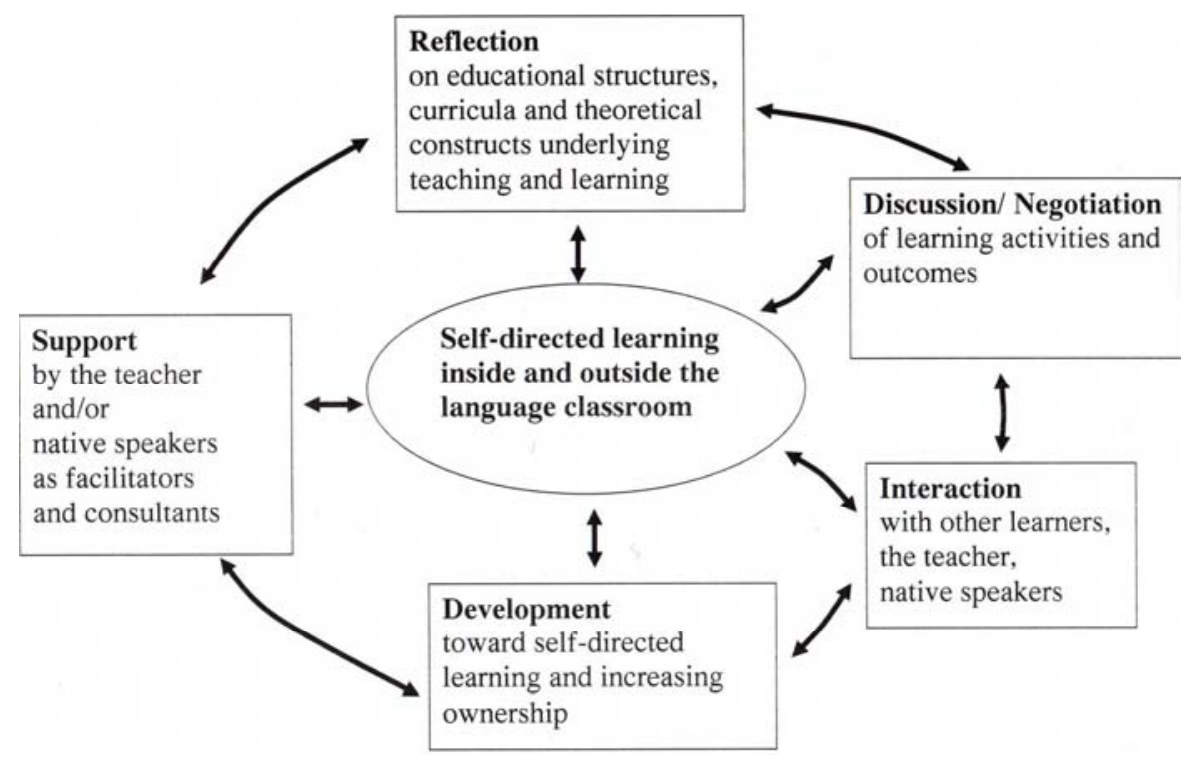

Figure 3: Main aspects of self-directed learning

- Reflection on conventional educational structures, on curricula and syllabuses including language policies, on available materials and media, on tasks, activities and exercises, on evaluation in the form of internal selfassessment and external tests, on theoretical constructs underlying language acquisition, e.g., on learning styles and learner strategies.

- Discussion/Negotiation of learning activities and learning outcomes in accordance with the overall aims of communicative intercultural competence and lifelong language learning.

- Interaction with other learners, with the teacher, with native speakers inside and outside the language classroom in order to arrive at a reflective use of available resources and to construct knowledge for themselves. 
- Support by the teacher and/or native speakers acting mainly in the role of facilitators and consultants which help learners to take control over the planning, organization and evaluation of their individual learning processes; supported by IT technologies which may facilitate self-access and selfassessment.

- Development of a shift from other-directed learning to self-direction, of competencies which allow increasing ownership and conscious use of all opportunities for learning the target language and other second/foreign languages.

\section{Continuing the example of self-directed learning of Turkish as a foreign language}

Having found an interlocutor in the student from Istanbul, most aspects of my learning changed notably. Before describing the ways in which reflection, discussion/negotiation, interaction and support led me to "my" personal form of self-directed learning, I will briefly illustrate a domain which remained unchanged, namely the learning of lexical items.

To memorize the vocabulary, I wrote every "new" word on a file card with the German translation on the reverse, generally adding a bit of context. To make sure that I was acquainted with the vocabulary learned, after a memorizing "session", I wrote down the words, expressions or sentences without looking at the cards. When I organized the cards afterwards in a box, I did not follow the usual suggestion of creating three sections: 1 . vocabulary to learn, 2 . vocabulary to repeat, 3 . vocabulary already learned. I simply organized the cards in alphabetical order. This procedure proved to be particularly useful for Turkish as it facilitated the comparison of lexical items which have a similar form, e.g., the verbs yakmak (to light, to burn), yapmak (to make), yatmak (to go to bed), yazmak (to write).

Since I learned Turkish outside the classroom, the focus of my attention was on available materials and on communication activities. It was the student's merit to explain to me why and in what respect the dialogs and other texts in the course book were inappropriate, or rather inauthentic. By negotiating and interacting with my consultant and several students of mine (of Turkish descent, most of them born in Germany) I began to understand the communicative value of particular ways of putting things. Furthermore, my "teacher" answered my numerous questions about grammatical structures and pragmatic conventions. In addition, we discussed why the authors of the textbook had chosen an Austrian and not a German as the protagonist of the texts. Was this choice motivated by the wish to avoid conflicts which might have emerged if the "learner" had been German? Later on I consulted 
an introduction to Turkish for tourists (Hueber Einstieg türkisch für Kurzentschlossene 2000). Even in this small course book, Peter Hassan, who comes to Istanbul as a visitor, is of Turkish and not of German origin.

Besides the need for cooperation even in self-directed learning outside the classroom, which I already touched upon above, my own example shows that the learning styles and strategies employed in language learning and language use are highly individual. But in what way do they determine foreign language learning? How can styles and strategies be "stretched" so as to gain more control over one's own learning and to improve learning outcomes?

\section{Styles and strategies in the context of learner autonomy}

\subsection{Learning styles}

Learning styles are the overall patterns that give general direction to learning behavior. Cohen and Dörnyei (2002: 176) underscore the well-known fact that different learners approach learning in a significantly different manner, and that the concept of learning styles has been used to refer to these differences. Learning styles seem to be relatively stable, and, thus, teachers may not have such a direct influence on this learner variable as with motivation. Furthermore, many learners do not favor one learning style to the exclusion of all others. Nevertheless, the identification of learning style dimensions, generally in the form of dichotomies, is useful to describe learners' style preferences. Cohen and Dörnyei (2002: 177) propose the following list of style preferences which are considered particularly relevant and useful to understanding the process of language learning:

- Being visual, auditory or hands-on.

- Being more extroverted versus introverted.

- Being more abstract and intuitive versus more concrete and thinking in stepby-step sequence.

- Preferring to keep all options open versus being closure-oriented.

- Being more global versus more particular.

- Being more synthesizing versus being more analytic.

The authors propose a reliable self-assessment instrument and provide detailed explanations to illustrate what these style dimensions involve in actual learning. This hands-on activity can be used to encourage learners to stretch their learning styles (see appendix I at the end of this article). 


\subsection{Learner strategies}

Learner strategies are any specific actions or behavior a student engages in, most often consciously, to improve his or her own learning. Whereas styles are general patterns, strategies are related to the task at hand. For Cohen and Dörnyei (2002: 178) research into the "good language learner" is at the origin of the strategy concept:

When learning and using an L2, learners may employ a number of strategies which are usually aimed at improving their performance. Secondlanguage researchers first noticed the importance of various learning strategies when they were examining the 'good language learner' in the 1970s.

As it is important for learners to be in command of a rich and personalized repertoire of language learning strategies and for their teachers to guide the students in their development, it is useful to go beyond the well-known categorization of strategies as cognitive, meta-cognitive, affective and social (Chamot 1987; Oxford 1990). Another helpful distinction is between language learning and communication strategies, the latter "referring to strategies for using the language that has been learned, however incompletely" (for more detail see Cohen and Dörnyei 2002: 178). In addition, strategies can be classified according to the skill area to which they relate. The authors (2002: $182 \mathrm{ff}$.) give a brief sampling of these strategies from which I quote the part referring to vocabulary, as these strategies cross-cut the four basic skills, i.e., the receptive skills of listening and reading and the productive skills of speaking and writing:

\section{Vocabulary strategies}

To memorize new words:

Analyzing words to identify the structure and/or the meaning of one or more of their parts

Making a mental image of new words whose meaning can be depicted.

In order to review vocabulary:

Going over new words often at first to make sure they are learned

Going back periodically to refresh one's memory about words previously learned. 
In order to recall vocabulary:

Making an effort to remember the situation where the word was heard or seen in writing, and if written, trying to remember the page or sign it was written on.

As a way of making use of new vocabulary:

Using words just learned to see if they work

Using familiar words in different combinations to make new sentences.

(Cohen and Dörnyei 2002: 183).

An obvious problem with all classifications is the continual shifting of the students from one of these categories to another. Another set of learner strategies needs to be mentioned. Besides the general distinction between learning strategies and communication strategies, we can observe - at least with a large number of learners - efforts to increase or protect their existing motivation. Self-motivating strategies may help students to preserve their original goals, to develop defensive routines to avoid distractions, to add extra attraction or interest to the tasks at hand, to manage disruptive emotional states and to create positive environmental influences (for more detail see Dörnyei 2001).

\subsection{Links between styles, strategies and tasks}

Just as all particular strategies are interrelated in various ways, so there are numerous links between general style preferences and specific strategy choices. Furthermore, these two variables are related to tasks, i.e., different tasks may evoke the use of different strategies. According to Skehan (1998) a task can be defined as an activity that satisfies the following criteria: it is primarily meaningful but may also be intended to elicit certain grammatical forms, it has a goal which needs to be worked towards, it is evaluated by means of the outcome, and it has a link to the real world. Cohen (2003: 281) adds that tasks will vary depending on:

1. The complexity of the task content (e.g., dealing with concrete and immediate information versus that which is abstract and remote),

2. The stressfulness of the communication (e.g., whether planning and performing the task is timed or not, whether spoken or written, whether performed alone or with others, whether the task itself is considered important and the importance of errors in performing it, and the control the speaker has over changing the goals of the task),

3. The ease of interpreting the task goal, 
4. The difficulty of the linguistic code itself (and whether the learners can avoid the use of language structures being targeted in the task),

5. The familiarity of the task type and the ease of performing it (e.g., one-way or two-way communication, open versus closed, fixed-answer responses).

So what can teachers do in order to broaden the styles and strategies of their language learners? Teachers can take the following main steps:

- find out about students' style and strategy preferences through appropriate tasks and the use of style and strategy surveys (cf. appendix I),

- raise learners' awareness of their learning styles and the strategies they use in particular exercises and tasks,

- explain the reasons for strategy use,

- model "style-stretching" and new strategies,

- provide exercises, activities and tasks to help students to try out "new" strategies,

- encourage students to improve their repertoires,

- give students the opportunity to discuss in sharing sessions what works best for them,

- underscore cross-cultural differences in the use of styles and strategies, especially communication strategies.

\subsection{Research questions}

As aforementioned, many researchers and practitioners view learning strategies as being in the focus of learner autonomy and, consequently, of effective learning. Apart from identification and classification, research on language learning strategies has taken two directions: correlation of strategy use with learning outcomes, and investigation of the possibility of training learners in strategy use (Benson 2001: 80).

Many experts in the field of learner autonomy are far away from establishing with certainty that explicit strategy training is appropriate for all language learners (see Cohen 1998 above 3.4). For Little (2000: 580) this training is vulnerable to criticism on at least four grounds:

First, 'it is not clear that what differentiates good or poor learners is the choice of strategy; it may simply be the range and amount of use of strategies' (McDonough, 1995: 83). Second, because most strategies can be deployed unconsciously as well as consciously, strategy training may 
simply make learners consciously aware of strategies they were already using unconsciously. Third, the existence of individual learning styles casts some doubt on the extent to which all strategies are in principle equally accessible to all learners. Fourth, metacognition is by no means an infallible guide to cognition (see Morris, 1990), so that we can never be certain that what learners think they are doing corresponds to underlying mental processes to which they have no introspective access.

Even if further inquiry into the complex relationship between strategy use and autonomy is needed, research has shown correlation between strategy use and improved language-learning performance (see e.g. the survey by Chamot and Rubin 1994). The effectiveness of particular strategies, however, "is influenced by variables such as proficiency level, task, text, language modality, background knowledge, context of learning, target language and learner characteristics" (Benson 2001: 145). There is much evidence that language-learning performance can be improved "through the ability to understand and deploy a personal set of effective strategies" (Chamot and Rubin 1994: 772).

Another important point is the cultural appropriateness of autonomy and the related issue of strategy training. A frequently voiced criticism of learner autonomy as a general goal is that it derives from liberal traditions in Western education and may thus be inappropriate in other educational contexts. To respond to this criticism we can appeal to the universal and the relative in human culture "arguing that autonomy is a hallmark of all truly successful learning but that the discursive practices by which it is developed are culturally conditioned and thus endlessly variable" (Little 2000: 71). Any language teacher who takes this position may try to work out with the students in what ways learner development improves language learning and its outcomes in a particular setting.

To summarize, we must distinguish between strategy use and training and the more general goal of learner autonomy. I suggest focussing on the following issues:

- The appropriate use of learner strategies may lead to better learning outcomes, but not necessarily to greater control over one's own learning.

- In many cases the implicit use of particular strategies, "triggered" by the task at hand, is more appropriate for language learners than explicit training.

- Explicit strategy training must allow for the individual procedures proposed by the individual learner.

- In any case discussion and reflection on the procedures employed are crucial. 
- It is reflection on learning in general, including styles and strategies, that may improve proficiency and lead to autonomy in language learning.

- Learner autonomy is not automatically linked to proficiency through strategy use, but greater control often leads to more success in language learning.

- Autonomy in language learning, i.e., the capability to self-direct learning (see 3.5 above), is a prerequisite for lifelong learning of second and foreign languages.

- The ultimate measure of success in second or foreign language learning is the extent to which the target language becomes an integrated part of the learner's identity.

\section{Enhancing the performance of $L 2$ speech acts}

\subsection{Pragmatic ability}

As the overall aim of language learning is to accomplish the communicative goals which language learners set themselves, pragmatic ability is of the greatest importance. What does pragmatic ability consist of? It comprises the ability to use pragmatic knowledge. In the 1970s this knowledge was mainly described as linguistic (Hymes 1972) in opposition to discoursal, sociolinguistic, or pragmatic competence. It was the merit of Bachman (1990) to include pragmatic competence as an important component in communicative language ability. In their modified model Bachman and Palmer (1996) replace pragmatic competence by the term of pragmatic knowledge which consists of functional knowledge (ideational, manipulative, instrumental, imaginative) and sociolinguistic knowledge, i.e., knowledge of conventions such as varieties, registers, idiomatic expressions, cultural references, figures of speech. The resulting difference between pragmalinguistics and sociopragmatics, i.e., how pragmatic principles operate in different cultures, has to be taken into account when teachers want to help their learners to obtain knowledge about speech acts and to perform them more effectively.

From results of research into Interlanguage Pragmatics (ILP) we know that even advanced L2 learners often fail to use the appropriate forms of speech acts. Whereas they are able to carry out straightforward tasks, e.g., to describe themselves to a person they are going to meet for the first time, their speech act performance is likely to reflect negative transfer from L1 norms. Researchers (e.g. Olstain and Blum-Kulka 1985; Baron 2003), point out that it can take many years for L2 speakers to have their performance reflect the norms of speech act behavior for a given speech community (see also Cohen 2005: 280). 
Performing speech acts in an appropriate way means adjusting their delivery to the situation, the age, the relative status, or the gender of the interlocutor. Cohen (2005: 279) underscores the complexity of performing speech acts in an L2:

Research has demonstrated that effective speech act performance entails not only strategically selecting and making use of the pragmalinguistic forms that are appropriate for the given speech act, such as in making a request ("Can I take ...?" vs. I was wondering if ..."), but also performing the speech act [e.g., a request for a car] in the right place, at the right time, given the sociopragmatic norms for that speech community or for that family unit in the given situation. So, whereas native speakers of English would most likely soften the request through syntactic mitigation (e.g., "I was wondering if ..."), nonnative speakers may well have learned this syntactic structure but would not necessarily have sufficient pragmalinguistic control over its use in their requests [...] (Bardovi-Harlig 2003).

\subsection{How to obtain information about (L2) speech acts}

Course books and other teaching and learning materials are quite often based on the intuitions of curriculum writers or textbook authors. These materials may reflect what native speakers think they do rather than what they do in real interactions. In other words, the speech acts reproduced in these materials do not correspond to what natives say in naturally-occurring settings. This criticism can also be made about production questionnaires, especially in the form of Discourse Completion Tests (DCTs). Golato (2003) compared natural data - responding to compliments in German L1 - with data collected by means of a DCT. She did not find the most frequent response strategies used in the DCT in the naturalistic data. It may be the absence of an interlocutor that induced the respondents to the DCT to expand their responses.

The main source for information about speech acts are corpora of pragmatic data "that can be drawn on to better understand how native speakers of a language actually realize speech acts in numerous contexts" (Cohen 2005: 281). Teaching and learning materials on pragmatics should, thus, be based on research. "There have also been recent studies focusing not on production of speech acts but on the ability to perceive which of a series of utterances would be the most appropriate in the given speech act situation" (Cohen 2005: 283, where a more detailed overview of research can be found; see also Safont Jordà 2005; Liu 2006).

How can corpora of naturalistic data be introduced into the foreign language classroom? First of all, it is the task of the teacher to compare speech acts in 
teaching and learning materials with those occurring in natural settings. Large collections of both spoken and written natural texts are stored on computers. Most of them are free of charge (for an introduction to Corpus Linguistics and how corpora can inform language teaching see Reppen and Simpson 2002). As our concern is to promote learner development and self-directed learning, teachers also have to help their students to make appropriate use of corpus data. At the outset guidance may consist in providing web addresses and links to adequate corpora (for a list see appendix II). Proceeding step by step, students may consult corpora to resolve linguistic problems that occurred in their own speaking and writing (e.g. the correct use of "like" or the difference between "to think of" and "to think about"). In a "research project" L2 learners with advanced proficiency can find out about different realizations of a speech act according to the variations mentioned above. In any case, the appropriate use of L2 data provided by Corpus Linguistics is an important component of self-directed language learning.

\subsection{How to teach pragmatic behavior}

Given the differences in pragmatic conventions between two and more speech communities and the included communities of practice, there is no doubt that learning about L2 pragmatics is a complex task for teachers and learners. What can be done in the foreign language classroom, especially in higher education?

The main question is whether learners are more successful in developing the necessary pragmatic ability through explicit or implicit learning. Explicit instruction in pragmatics has been gaining ground in recent years. There are edited volumes reflecting practical efforts to teach pragmatics which contain lesson plans such as Bardovi-Harlig and Mahan-Taylor (2003). As students' L2 textbooks and other curricular materials do not provide sufficient focus on speech acts, it is advisable to consult data collections from natural settings (see 5.2 above). Reppen and Simpson (2002: 108) have this to say on the matter: "Perhaps the most exciting possibility is that corpus linguistics now gives students and teachers the ability to explore for themselves the way that various aspects of language are used, helping to guide them toward their language goals."

Classroom instruction may consist of "description, explanation and discussion of pragmatic features" (Safont Jordà 2005: 114). There are empirical studies that seem to prove the advantage of an explicit approach to pragmatic instruction over more implicit teaching and learning (see Trosberg 2003). Cohen (2005: 285) reports on research by Takahashi (2001) into pragmatic performance involved in the development of English request strategies. In this study four input conditions were used: 1) explicit teaching of requests, 2) having learners compare their utterances to those of native speakers, 3) having learners compare the utterances of 
other EFL learners to those of natives, and 4) having learners read transcripts of interactions and answer comprehension questions about the content. The first condition, "explicit teaching", has the strongest impact.

In my opinion, explicit focus on pragmatic conventions as used in regular classroom instruction is not sufficient. In easier tasks such as detecting syntactic features from L2 texts an inductive approach combined with explanation and discussion may suffice. In the case of a complex task such as developing pragmatic ability in accordance with L2 conventions, students must be guided to develop strategies, both strategies for learning and strategies for performing speech behavior. They are to develop more specialized speech act performance strategies and to fine-tune their repertoires.

\subsection{Working with a taxonomy of learner strategies for acquiring speech acts}

Despite his own warnings against an overemphasis on strategy training, Cohen (2005: 287ff.) proposes a taxonomy which identifies key learner strategies in the acquisition of speech acts.

This taxonomy, which should be viewed as a series of hypotheses in need of empirical validation, provide strategies for the perception, interpretation and production of L2 speech acts. I reproduce it in an abridged and adapted version inviting teachers and students to try out what works for them in their own particular (EFL) learning context (for a full version of the taxonomy see Cohen 2005: 288292).

\section{Speech act learning strategies}

- Taking practical steps to gain knowledge of how specific speech acts work by

1. identifying the L2 speech acts to focus on, using criteria such as:

a. their frequency of use in common situations (e.g., requesting, refusing, thanking),

b. their potentially high-stakes value in discourse (e.g., apologizing, complaining),

c. their special role in the given community of practice (e.g., use of expletives).

2. gathering information through observation, interview, and written material (e.g., at the workplace: e.g., refusing request made by people of higher status).

- Conducting a "lay" cross-cultural analysis by

1. thinking through what the appropriate speech act in L1 would be, 
2. identifying the norms for performance in the target speech community,

3. assuming they can be performed in the given situation, identifying

a. the semantic formulas that tend to be used (e.g., whether an offer of repair is expected to be given in that apology situation),

b. the linguistic structures to use (e.g., whether to use the word "apologize" or just "sorry", whether to intensify with words like "really", "awfully" etc.), determining the similarities and differences between the two cultures, obtaining a viable interpretation for the crosscultural differences (e.g., by asking members of the L2 speech community).

- Observing what native speakers do by noting what they say, how they say it (speed of delivery, tone, etc.), and their nonverbal behavior as they say it (facial expressions, body posture, and gestures).

- Asking natives (instructors and non-instructors) to model performance of the speech acts. A key goal of the learner would be to see if there is variation in the realization of the speech act(s).

- Accessing published materials dealing with speech acts:

1. websites with instructional materials on speech acts,

2. corpora in the target L2 that provide samples of the given speech acts in numerous contexts,

3. L2 textbooks which have coverage of the speech acts of interest.

\section{Speech act use strategies}

- Devising and then utilizing a memory aid for retrieving the speech act material that has already been learned (e.g., visualizing a listing of the semantic formulas for a given speech act and then scanning down this list in order to select the appropriate speech acts).

- Practicing those aspects of speech act performance that have been learned:

1. engaging in imagery interactions,

2. engaging in speech act role play with fellow learners of the L2,

3. engaging in "real play" with native speakers.

- Asking native speakers for feedback.

- Determining their learning style preferences and then trying out an approach to speech act delivery.

- Using communication strategies to get the message across: 
1. using an alerter as a social strategy (e.g., "I want to say I'm sorry, but I'm not sure to say it right ..."),

2. upon delivering the speech act, using metapragmatic statements to repair the situation in the case of possible or actual pragmatic failure,

3. attempting to approximate what native speakers might do in that speech act situation.

- Having the knowledge to perform the speech act appropriately but remaning true to their own inclinations in their speech act delivery, rather than being overly native like.

\section{Metapragmatic considerations}

It is up to the learners to determine the speech act(s) they will work on and the aspects of performance that will get attention.

With regard to metacognitive strategies, the learner needs to determine how much pre-planning of the speech act to do beforehand, as well as the nature of the monitoring that will go on during its delivery and the evaluation that will go on afterwards.

\section{Concluding remark}

Whereas research in the 1970s and 1980s focused on the "good language learner", there has since been an increasing tendency to talk about "success" in language learning and hence "the successful learner". It is to be hoped that this shift will bring about a change in attitudes, whereby knowledge of second and foreign languages is measured against the success of bringing people all over the world closer together.

\section{Appendix I}

\section{Learning Style Survey}

Cohen and Dörnyei (2002: 188-200) suggest the following hands-on-activity designed to assess language learner's general approach to learning (see also Oxford 1993). The task of the students is to fill in the survey, then total their points, and based on their scores, consider their overall learning preferences. At the end of this survey specific guidelines on how to interpret the scores of the learners will be provided. The survey is designed for adolescents and adults with a good command of English. If the teachers wants students without sufficient knowledge of English or children to do the following hand-on-activity, explanations and even translations in the L1 will be necessary. 


\section{Learning Style Survey (for the students)}

For each item, circle your immediate response:

- $0=$ Never

- 1 = Rarely

- 2 = Sometimes

- $3=$ Often

- 4 = Always

\section{Part 1: How I Use My Physical Senses}

I remember something better if I write it down

$\begin{array}{lllll}0 & 1 & 2 & 3 & 4\end{array}$

I understand lectures better when they write on the board

$\begin{array}{lllll}0 & 1 & 2 & 3 & 4\end{array}$

Charts, diagrams and maps help me understand

what someone says

$\begin{array}{lllll}0 & 1 & 2 & 3 & 4\end{array}$

Visual-Total ...

I remember things better if I discuss them with someone

$\begin{array}{lllll}0 & 1 & 2 & 3 & 4\end{array}$

I prefer to learn by listening to a lecture rather than reading

$\begin{array}{lllll}0 & 1 & 2 & 3 & 4\end{array}$

I like to listen to music when I study

$\begin{array}{lllll}0 & 1 & 2 & 3 & 4\end{array}$

Auditory-Total ...

I need frequent breaks when I work or study

$\begin{array}{lllll}0 & 1 & 2 & 3 & 4\end{array}$

If I have a choice between sitting and standing,

$\begin{array}{lllll}0 & 1 & 2 & 3 & 4\end{array}$

I'd rather stand

I think better when I move around

(for example, pacing or tapping my feet)

$\begin{array}{lllll}0 & 1 & 2 & 3 & 4\end{array}$

Part 2: How I Expose Myself to Learning Situations

I learn better when I work or study with others than by myself $\quad \begin{array}{llll}0 & 1 & 2 & 3\end{array} 4$

I meet new people easily by jumping into the conversation

$\begin{array}{lllll}0 & 1 & 2 & 3 & 4\end{array}$

It is easy for me to approach strangers

$\begin{array}{lllll}0 & 1 & 2 & 3 & 4\end{array}$

Extroverted-Total...

I am energized by the inner world (what I'm thinking inside)

$\begin{array}{lllll}0 & 1 & 2 & 3 & 4\end{array}$

I prefer individual or one-on-one games and activities

$\begin{array}{lllll}0 & 1 & 2 & 3 & 4\end{array}$ 
When I am in a large group, I tend to keep silent and just listen $\quad \begin{array}{lllll}0 & 1 & 2 & 3 & 4\end{array}$ Introverted-Total ...

\section{Part 3: How I Handle Possibilities}

I have a creative imagination

$\begin{array}{lllll}0 & 1 & 2 & 3 & 4\end{array}$

I add many original ideas during class discussions

$\begin{array}{lllll}0 & 1 & 2 & 3 & 4\end{array}$

I am open-minded to new suggestions from my peers

$\begin{array}{lllll}0 & 1 & 2 & 3 & 4\end{array}$

Random-Intuitive-Total ...

I read instruction manuals before using the device

$\begin{array}{lllll}0 & 1 & 2 & 3 & 4\end{array}$

I trust concrete facts instead of new, untested ideas

$\begin{array}{lllll}0 & 1 & 2 & 3 & 4\end{array}$

I prefer things presented in a step-by-step way

$\begin{array}{lllll}0 & 1 & 2 & 3 & 4\end{array}$

Concrete-Sequential-Total ...

\section{Part 4: How I Approach Tasks}

My notes and my school materials are carefully organized

$\begin{array}{lllll}0 & 1 & 2 & 3 & 4\end{array}$

I write lists of everything I need to do each day

$\begin{array}{lllll}0 & 1 & 2 & 3 & 4\end{array}$

I enjoy a sense of structure in the classroom

$\begin{array}{lllll}0 & 1 & 2 & 3 & 4\end{array}$

Closure-Oriented-Total ...

I gather lots of information, and then I make last-minute decisions $\begin{array}{llllll}0 & 1 & 2 & 3 & 4\end{array}$

I prefer fun or open activities rather than structured activities $\quad \begin{array}{lllll}0 & 12 & 3 & 4\end{array}$

My schedule is flexible for changes

$\begin{array}{lllll}0 & 1 & 2 & 3 & 4\end{array}$

Open-Total ...

\section{Part 5: How I Deal with Ideas}

I can summarize information easily

$\begin{array}{lllll}0 & 1 & 2 & 3 & 4\end{array}$

I enjoy tasks where I have to pull together ideas

$\begin{array}{lllll}0 & 1 & 2 & 3 & 4\end{array}$

to form one large idea

By looking at the whole situation, I can easily understand some $\quad \begin{array}{lllll}0 & 1 & 2 & 3 & 4\end{array}$ Synthesizing - Total ...

I prefer to focus on grammar rules

$\begin{array}{lllll}0 & 1 & 2 & 3 & 4\end{array}$ 
or contrast two things

I'm good at solving complicated mysteries and puzzles

$\begin{array}{lllll}0 & 1 & 2 & 3 & 4\end{array}$

Analytic - Total ...

\section{Part 6: How I Deal with Input}

It is easy for me to see the overall plan or big picture

$\begin{array}{lllll}0 & 1 & 2 & 3 & 4\end{array}$

I get the main idea, and that's enough for me

$\begin{array}{lllll}0 & 1 & 2 & 3 & 4\end{array}$

When I tell an old story, I tend to forget lots of specific details

$\begin{array}{lllll}0 & 1 & 2 & 3 & 4\end{array}$

Global - Total ...

I need very specific examples in order to understand fully

$\begin{array}{lllll}0 & 1 & 2 & 3 & 4\end{array}$

I can easily break down big ideas into their smaller parts

$\begin{array}{llllll}0 & 1 & 2 & 3 & 4\end{array}$

I pay attention to specific facts or information

$\begin{array}{lllll}0 & 1 & 2 & 3 & 4\end{array}$

Particular - Total ...

\section{Suggested Solutions}

Cohen and Dörnyei (2002: 297-298) give the following descriptions of learning style preferences. These descriptions give the learner an idea of his or her tendencies when learning. The teacher may discuss them with the learners in a plenary session. Opting for learner development towards self-directed learning it is much better to hand the following list out to the students so that they can verify their results by themselves.

\section{Suggested Solutions (for the students)}

\section{Part 1: How I Use my Physical Senses}

If you are a visual person, you rely more on the sense of sight, and you learn best through visual means (Books, video, charts, pictures). If you are an auditory person, you prefer listening and speaking activities (discussions, debates, audio tapes, role-plays, lectures). If you are a tactile/kinesthetic person, you benefit from doing projects, working with objects and moving around the room (games, building models, conducting experiments). 


\section{Part 2: How I Expose Myself to Learning Situations}

If you extroverted, you enjoy a wide range of social, interactive learning tasks (games, conversations, discussions, debates, role-plays, simulations). If you are introverted, you like to do more independent work (studying or reading by yourself or learning with the computer) or enjoy with one other person you know well.

\section{Part 3: How I Handle Possibilities}

If you are a random-intuitive, you are more future-oriented, prefer what can be over what is, like to speculate about possibilities, enjoy abstract thinking and avoid step-by-step instruction. If your preference is concrete-sequential, you are presentoriented, prefer one-step-at-a-time activities, and want to know where you are going in your learning at every moment.

\section{Part 4: How I Approach Tasks}

If you are more closure-oriented, you focus carefully on all learning tasks, meet deadlines, plan ahead for assignments and want explicit directions. If you are more open in your orientation, you enjoy discovery learning (in which you pick up information naturally) and prefer to relax and enjoy your learning without concern for deadlines or rules.

\section{Part 5: How I Deal with Ideas}

If you are a synthesizing person, you can summarize material well, enjoy guessing meanings and predicting outcomes, and notice similarities quickly. If you are analytic, you can pull ideas apart, do well on logical analysis and contrast tasks, and tend to focus on grammar rules.

\section{Part 6: How I Deal with Input}

If you are a global person, you enjoy getting the main idea and you are comfortable communicating even if you don't know all the words or concepts. If you are a particular person, you focus more on details, and remember specific information about a topic well.

\section{Appendix II}

Useful Websites for Corpus Linguistics (see Reppen and Simpson 2002: 109110): 
- web.bham.ac.uk/johnstf/timconc.htm

Tim Johns' Data Driven Learning Page with numerous links to corpus-based data-driven learning and teaching materials, as well as more general links related to corpora and language teaching. (2007-02-28)

- www.liv.ac.uk/ ms2928/homepage.html

Homepage of Mike Scott, author/developer of Wordsmith Tools, a concordancing and text analysis program. (2007-02-28)

- visl.hum.ou.dk/visl/en

Site of the 'Visual Interactive Syntax Learning' project at the University of Southern Denmark; a set of online text databases and automatic text analysis tools for classroom teaching and scholarly research. (2007-02-28)

- www.hti.umich.edu/m/micase

Online access to transcripts of the Michigan Corpus of Academic Spoken English (MICASE), including search facility for browsing specified transcripts and key-word-in context concordance search function. (2007-0228)

- info.ox.ac.uk/bnc

Homepage of the British National Corpus, with links to the BNC online service, a simple search function, and order forms for purchasing the full 100-million-word corpus or the sampler. (2007-02-28)

- americannationalcorpus.org

Home page of the American National Corpus provides information on the design and construction (in progress) of a 100-million-word corpus of American English with a similar design to the BNC. (2007-02-28)

\section{References}

Bachman, L. F. (1990). Fundamental Considerations in Language Testing. Oxford: Oxford University Press.

Bachman, L. F.andPalmer, A. (1997). Language Testing in Practice. Oxford: Oxford University Press.

Bardovi-Harlig, K. (2003). Understanding the role of grammar in the acquisition of L2 pragmatics. Martínez Flor, A. et al. (eds.): Pragmatic Competence and Foreign Language Teaching. Castelló de la Plana/Spain: Publicacions de la Universitat Jaume I, 25-44. 
Bardovi-Harlig, K./Mahan-Tylor, R. (eds.) (2003). Teaching Pragmatics. Washington, DC: U.S. State Department on-line. http.//exchanges.state.gov.education/engteaching/pragmatics.htm

Barron, A. (2003). Acquisition in Interlanguage Pragmatics. Learning How to Do Things with Words in a Study Abroad Context. Amsterdam/Philadephia: John Benjamins.

Benson, P. (2001). Teaching and Researching. Autonomy in Language Learning. Harlow et al.: Pearson.

Benson, P./Voller, P. (eds.) (1997). Autonomy and Independence in Language Learning. London: Longman.

Block, D. (2004). Globalization and language Teaching. ELT Journal 58.1, 75-76.

Chamot, A. U. (1987). The learning strategies of ESL students. Wenden, A./Rubin, J. (eds.). Learner Strategies in Language Learning. Englewood Cliffs, NJ: Prentice Hall, 71-84.

Chamot, A. U./Rubin, J. (1994). Comments on Jamie Rees-Miller's 'A critical appraisal of learner training. theoretical bases and teaching implications'. Two readers react. TESOL Quarterly 28.4, 771-776.

Cherrington, R. (200). Linguistic imperialism. Byram, M. (ed.). Routledge Encyclopedia of Language Teaching and Learning. London: Routledge, 360-362.

Cohen, A. D. (1998). Strategies in Learning and Using a Second Language. London: Longman.

Cohen, A. D. (2003). The learner's side of foreign language learning. Where do styles, strategies, and tasks meet? International Review of Applied Linguistics in Language Teaching 41.4, 279-291.

Cohen, A. D. (2005). Strategies for learning and performing L2 speech acts. Intercultural Pragmatics 2.3, 275-301.

Cohen, A. D./Dörnyei, Z. (2002). Focus on the language learner. Motivation, styles, and strategies. Schmitt, N. (ed.). An Introduction to Applied Linguistics. London: Edward Arnold, 170-190.

Dam, L. (1995). Learner Autonomy 3: from Theory to Classroom Practice. Dublin: Authentik.

Dam, L. (1999). How to develop autonomy in a school context - how to get teachers to change their practice. Edelhoff, C./ Weskamp, R. (Hrsg.). Autonomes Fremdsprachenlernen. Ismaning: Hueber, 113-133.

Dickinson, L. (1987). Self-instruction in Language Learning. Cambridge: Cambridge University Press.

Dickinson, L./Wenden, A. (1995). Special issue on autonomy. System 23.2.

Dörnyei, Z. (2001). Teaching and Researching: Motivation. Harlow: Longman.

Ellis, R. (2003). Task-based Language Learning and Teaching. Oxford: Oxford University Press. 
Ellis; R. (1994). The Study of Second Language Acquisition. Oxford: Oxford University Press.

Giddens, A. (1990). The Consequences of Modernity. Cambridge: Polity Press.

Golato, A. (2003). Studying compliment responses. A comparison of DCTs and recordings of naturally occurring talk. Applied Linguistics 24, 90-121.

Graddol, D. (1997). The Future of English? A guide to forecasting the popularity of the English language in the 21st century. London: British Council.

Holec, H. (1981). Autonomy in Foreign Language Learning. Oxford: Pergamon.

Hymes, D. (1972). On communicative competence. Pride, B. J./Holmes, J. (eds.). Sociolinguistics. Harmondsworth: Penguin.

Kramsch, C./Sullivan, P. (1996). Appropriate Pedagogy. ELT Journal 50.3, 199-212.

Legenhausen, L. (1999). Traditional and autonomous learners compared. the impact of classroom culture on communicative attitudes and behaviour. Edelhoff, C./ Weskamp, R. (Hrsg.). Autonomes Fremdsprachenlernen. Ismaning: Hueber, 166-182.

Legutke, M./Thomas, H. (1991). Process and Experience in the Language Classroom. London: Longman.

Little, D. (1990). Autonomy in Language Learning. Gathercole, I. (ed.). Autonomy in Language Learning. London: CILT, 7-15.

Little, D. (1996). Strategic competence considered in relation to strategic control of the language learning process. Holec, H. et al.. Strategies in language learning and use. Studies towards a common European framework of reference for language learning and teaching. Strasbourg: Council of Europe.

Little, D. (2000). Autonomy and autonomous learners. Byram, M. (ed.). Routledge Encyclopedia of Language Teaching and Learning. London: Routledge, 6972.

Lui, J. (2006). Measuring Interlanguage Pragmatic Knowledge of EFL Learners. Frankfurt/Main et al.: Lang.

McDonough, S. H. (1995). Strategy and skill in learning a foreign language. London: Arnold.

Morris, P. E. (1990). Metacognition. Eysenck, M. W. (ed.). The Blackwell Dictionary of Cognitive Psychology. Oxford: Blackwell, s. v.

Olshtain, E./Blum-Kulka, S. (1985). Degree of approximation. Non-native reactions to native speech act behavior. Gass, S./Madden, C. (eds.). Input in Second Language Acquisition. Rowley, MA: Newbury House, 303-325.

Oscarson (1997). Self-assessment of foreign and second language proficiency. Clapham, C./Corson, D. (eds.). Language Testing and Assessment. Encyclopedia of Language and Education. Volume 7. Dordrecht: Kluwer, 175-187. 
Oxford, R. L. (1990). Language Learning Strategies. what every Teacher should Know. Rowley, MA: Newbury House.

Oxford, R. L. (1995). Style Analysis Survey (SAS): assessing your own learning and working styles. Reid, J. M. (ed.). Learning Styles in the ESL/EFL Classroom. M Boston, MA: Heinle \& Heinle, 208-215.

Phillipson, R. (1992). Linguistic imperialism. Oxford: Oxford University Press.

Reppen, R./Simpson, R. (2002). Corpus Linguistics. Schmitt, N. (ed.). An Introduction to Applied Linguistics. London: Edward Arnold, 92-111.

Safont Jordà, M. P. (2005). Third Language Learners. Pragmatic Production and Awareness. Clevedon: Multilingual Matters.

Skehan, P. (1998). Task-based instruction. Annual Review of Applied Linguistics 18, 268286.

Takahashi, S. (2001). The role of input enhancement in developing pragmatic competence. Rose, K. R./Kapser, G. (eds.). Pragmatics in Language Teaching. Cambridge: Cambridge University Press, 171-199.

Trosberg, A. (2203). The teaching of business pragmatics. Martínez Flor, A. et al. (eds.). Pragmatic Competence and Foreign Language Teaching. Castelló de la Plana/Spain: Publicacions de la Universitat Jaume I, 247-281.

Vieira, F. (1999). Pedagogy for autonomy. exploratory answers to questions any teacher should ask. Müller-Verweyen, M. (ed.). Standpunkte zur Sprach- und Kulturvermittlung 7. Neues Lernen, Selbstgesteuert, Autonom. München: Goethe-Institut, 53-72.

Wenden, A. (1991). Learner Strategies for Learner Autonomy. London: Prentice Hall

Widdowson, H. G. (2000). English. Byram, M. (ed.). Routledge Encyclopedia of Language Teaching and Learning. London: Routledge, 193-196.

\section{Turkish Course Books:}

Hepsöyler, E./Liebe-Harkort, K. (1995). Türkisch mit Gedichten (Şiirle Türkçe Öğrenmek). Hückelhoven: Schulbuchverlag Anadolu.

Turan, T. (1997). Langenscheidts Praktisches Lehrbuch Türkisch. Berlin/München: Langenscheidt.

Scheffler, K.-H. (22005). Einstieg türkisch. Ismaning: Hueber. 